\section{The Rise and Fall of the Ediacaran Biota}

\author{
Edited by Patricia Vickers-Rich \\ and Patricia Komarower
}

Geological Society Special Publication No. 286, 2007, 456p., Price: $£ 95.00$ ISBN: 978-1-86239-233-5

A galaxy of palaeontologists from all five continents specializing in investigating the remains and traces of soft-bodied life forms of the Ediacaran time gathered in Prato (Italy) in 2004 and then in Kyoto (Japan) in 2006 to announce new discoveries and hypotheses, and more importantly, to thrash out controversies, contradictions, and even to debate prevailing consensus. Under the able stewardship of Patricia Vickers-Rich and Patricia Komarower (Editors) and very wise support from UNESCO (IGCP 493), they have published a definitive book on the Rise and Fall of the Ediacaran Biota. The Publications Office of the Geological Society deserves much of the credit for achieving such a remarkable feat in such a short time. This book is an excellent companion to the two erudite 'trade books' namely, The Rise of Animals by Fedonkin et al. and Life on a Young Planet by Andrew Knoll.

The organization of the papers in the book makes navigation a little difficult for the uninitiated. The excellent account of the beginning of research in Ediacaran life-forms by Sprigg, Glaessner and Wade (Turner and Vickers-Rich, pp. 443-446), tucked away near the tail end of short papers, would have piqued the attention of any reader had it been the first paper of the book. The papers are grouped rather loosely into six topics (General Geology, Correlation and naming, Micropalaeontology, Ediacarans, Body plans, Functional morphology, PrecambrianCambrian transition) and a section of seven short papers. The groups, quite understandably, overlap on the topics of other groups. For example, the papers grouped under General Geology, Correlation and Precambrian-Cambrian Transition, have much in common as many of them deal principally with stratigraphy while one deals with the methodology to detect cyclicity (e.g., Katsuta et al., pp. 27-34).

Organization aside, the book is a collection of excellent papers weaved around the central theme of Ediacaran biota.
Stratigraphy and palaeobiology sensu latu very reasonably dominate the disciplines the authors address. Several authors describe detailed litho-stratigraphic successions and then tie them to biostratigraphy. They use as much of radiometric geochronologic data as are available to peg the stratigraphic columns to absolute ages. The lack of many intercalated tuff within Ediacaran successions, however, prevents achieving the age-resolution of the time-scale as is becoming prevalent in the Phanerozoic. Carbon and strontium isotope stratigraphy provide a proxy for robust geo-chronology. Some authors have ingeniously combined biostratigraphy and isotopic stratigraphy to propose correlations within and between isolated basins extending even to continental scales. The paper by Grey and Calver (pp. 115-135) is a case in point. They use various types of data sets including seismic profiles and drill-hole logs to construct a sequence stratigraphic model and correlate the Ediacaran deposits in the Adelaide Rift Complex and the Amadeus and Officer basins. Their seemingly futuristic challenge to construct global correlation is valiantly addressed by Chumakov (pp. 15-26; fig. 1 on pp.16-17) who deduces climate-zonality and correlation to support the concept of partial Snowball Earth. These and several other papers are much thought provoking with testable inferences. A one page editorial diagrammatic summary of the distribution of diversity or preservation through the Ediacaran time would have helped the reader to comprehend if life-forms exploded, declined and then became extinct or gave rise to the Cambrian explosion.

In this vein one might ask: what were the causes for the rise and fall of the Ediacaran biota? Variations in ocean chemistry especially salinity, atmospheric composition especially $\mathrm{CO}_{2}$ content, climate especially temperature, etc. are called upon in many papers especially those dealing with Proterozoic-Phanerozoic transition. These variables, however, are not explicitly treated in any paper devoted to independent evidence from other disciplines. A few invited review papers from 'outsiders' would have made this book more useful albeit at the cost of diluting the focus of the IUGS meetings.

A very welcome group of papers report new discoveries of and new insights into wellpreserved Ediacaran fossils (for example, Jenkin and Nedin, 195-222; Fedonkin et al., 157-179), which can be used to reconstruct the live-forms of the time. Indeed, Laflamme et al. (pp. 237-257) produce an intriguing 3-D reconstruction of Charnia and judiciously infer their life habits. The discovery, perhaps by serendipity, of Ventogyrus revealing their intricate "internal construction" (p. 189; fig 4) clearly indicates that more painstaking work will likely result in finding many more specimens of the kind. Given that we are dealing with impressions of soft-bodied animals and other organisms, these papers record amazing advances. Investigations of functional morphologies and inferring kinship are not restricted to the fossils in the Phanerozoic domain any more. However, seeming similarities of functional morphologies of Ediacaran and Phanerozoic do not necessarily indicate taxonomic relationships as is expounded by Antcliffe and Brasier (pp. 377-386). Therefore, it is reasonable to clamor for learning much more about relevant assemblages of Hox genes to better understand the body plans of the Ediacaran bilateria (Valentine, pp. 369-375).

A hallmark of good science in this book is the inclusion of open criticism and cautionary notes. For example, Trusler et al. (pp. 181-185) draw attention to the problem of pattern recognition that truly forms the basis of identifications of impressions and traces. They put a very realistic advisory note about reconstructing Kimberella, much of which depends on subjective interpretations and extrapolation of patterns. Maithy and Kumar (pp. 315-330) boldly declare that identification of many putative Ediacaran fossils in the Proterozoic rocks in India are "dubious" (p. 327). This conclusion is likely to be true for misidentifications elsewhere as well, which would put enough doubts, for example, in the list of discoid Ediacaran fossils (Mac-Gabhann, Table 1, p. 298). Not very many books of the kind display such scientific integrity.

This book should be on the shelves of all geology libraries and should rank as a "mustread' for all investigators of Precambrian biota. Sedimentologists and stratigraphers would also benefit from reading selected papers as will geochronologists, oceanographers, atmospheric scientists.
Abhijit Basu
Department of Geological Sciences
Indiana University,
Bloomington, Indiana - 47405
USA
Email: basu@indiana.edu 